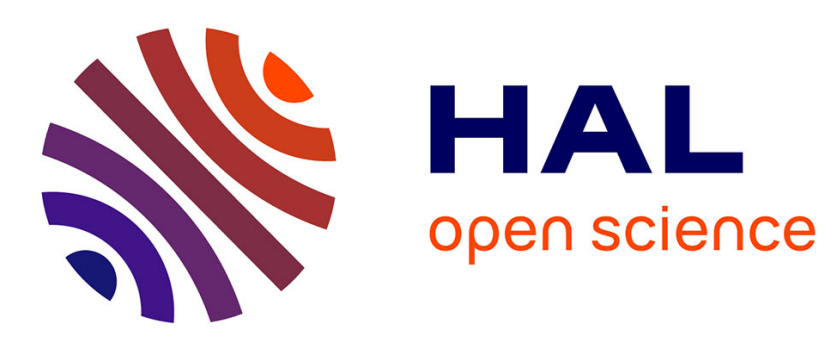

\title{
The contribution of the Internet to the strategic positioning of Small Businesses in the tourism industry
}

Véronique Favre Bonte, Sébastien Tran

\section{To cite this version:}

Véronique Favre Bonte, Sébastien Tran. The contribution of the Internet to the strategic positioning of Small Businesses in the tourism industry. International Journal of Entrepreneurship and Small Business, 2015, 25 (3), 10.1504/IJESB.2015.069698 . hal-01278933

\section{HAL Id: hal-01278933 \\ https://hal.science/hal-01278933}

Submitted on 8 Feb 2018

HAL is a multi-disciplinary open access archive for the deposit and dissemination of scientific research documents, whether they are published or not. The documents may come from teaching and research institutions in France or abroad, or from public or private research centers.
L'archive ouverte pluridisciplinaire HAL, est destinée au dépôt et à la diffusion de documents scientifiques de niveau recherche, publiés ou non, émanant des établissements d'enseignement et de recherche français ou étrangers, des laboratoires publics ou privés. 


\title{
Note de l'auteur
}

\section{The contribution of the Internet to the strategic}

\section{positioning of Small Businesses in the tourism industry}

Favre-Bonté Véronique (IREGE, Université Savoie Mont Blanc) et Tran Sébastien (DRM, Dauphine Recherches en Management)

\begin{abstract}
Small and Medium-sized Entreprises (SMEs) represent a significant share of firms in industrialized countries. However, little work is available concerning Small Businesses (SB) that have less than 50 employees (according to the majority of official definitions). ICT are considered a contributing factor in the renewal of competitiveness, in particular by reducing constraints that bear on SMEs. In this context, one can ask under what conditions the implementation of a website may change the strategic positioning of small accommodation businesses in the tourism sector.
\end{abstract}

Keywords: Internet ; Small Businesses ; Tourism ; Websites.

\section{Introduction}


Small and Medium-sized Entreprises ${ }^{1}$ (SMEs) represent a significant share of firms in industrialized countries. For example, they accounted for nearly 99\% of companies in the European Union (Eurostat ${ }^{2}$ ). Many works have focused their attention on the issues that are specific to such businesses, whether on their business model, their management or strategy (Julien, 1998). However, little work is available concerning Small Businesses (SB) that have less than 50 employees (according to the majority of official definitions). In 2003, they represented nearly 92\% of European companies according to the Observatory of European SMEs (Harindranath et al., 2008). Moreover, OECD member countries play a leading role in international tourism, representing 66\% of global arrivals while EU member countries accounted for $50.2 \%$ in 2010. Tourism sector also contributes 4.4\% of GDP for EU members ${ }^{3}$. In France tourism plays a major economic role with a large number of SMEs and VSEs $(235,000$ in 2009, in France). This sector is quite advanced in the use of ICT, where information is at the heart of services (Aldebert and Loufrani-Fedida, 2010). In 2010, e-tourism weighed more than 8 billion Euros (excluding business travel), up 19\% compared to 2009. After growing $6 \%$ in 2009, e-tourism benefits in full from the pick-up in the overall market. Also, according CCM Benchmark, in 2010, e-tourism represented 46.1\% of all e-commerce B-to-C in France.

This suggests a strong use of ICT for sales and marketing, a hypothesis supported in several works and studies. Bonn et al. (1998), show that Internet marketing is suitable for tourism products and services. Some research suggests developing a better understanding of the profile and behaviour of Internet surfers and shoppers (Sigala, 2004). Yet, in France, its use by SMEs remains low: only 12\% have a website that offers online transactions (Eurostat 2010).

\footnotetext{
${ }^{1}$ SMEs are defined by the European Commission as having less than 250 persons employed. They should also have an annual turnover of up to EUR 50 million, or a balance sheet total of no more than EUR 43 million according to Commission Recommendation of 6 May 2003.

${ }^{2}$ http://epp.eurostat.ec.europa.eu/statistics_explained/index.php/Small_and_medium-sized_enterprises

${ }^{3}$ http://www.oecd.org/cfe/tourism/oecdtourismtrendsandpolicies2012.htm
} 
Although SMEs are aware of the main benefits of ICT, 46\% of SMEs in France remain sceptic about its ability to develop their turnover (France Numérique 2012, p. 56). One current concern for governments and institutions lies in the use and contribution of technology to business development. Indeed, ICT are considered a contributing factor in the renewal of competitiveness, in particular by reducing constraints that bear on SMEs (Sullivan, 1985; Raymond et al., 2005; Amabille and Gadille, 2006; Qiang et al 2006, Matthews, 2007; Bellaaj, 2009). In this context, one can ask under what conditions the implementation of a website may change the strategic positioning of small accommodation businesses in the tourism sector.

Given the heterogeneity of activities in the tourism industry, we focused our attention on hospitality businesses in general (campsites, hotels, spas), which represented more than 20\% of companies in France in 2007 (INSEE, EAE services 2007) and are often at the heart of the tourist activity (this is the second activity in the sector in terms of turnover after catering). Our analysis focuses on Websites because in the Technology Acceptance Model (TAM), it is one of the ebusiness adoption constructs (Heijden, 2003; Cass and Fenech, 2003). Our problematic is therefore to understand "under what conditions can the implementation of a website change the strategic positioning of small accommodation businesses in the tourism sector?”.

The objective of this paper is twofold. Firstly, it aims to show that despite their small size, companies are able to use the Internet for their marketing and to develop sales. It also aims to show that, from a certain point and under certain conditions, the Internet can also change the strategic positioning of SMEs. In the first part of the article, we will review the role that the Internet plays in the development of SMEs. In the second part, after having exposed our 
methodological choices and the case studies, we will show the impact for accommodation businesses of implementing a website, but also several implications with respect to their managers.

\section{The role of ICT and the Internet in the development of SMEs}

Despite the constraints inherent to their small size, SMEs can use ICT to maintain or enhance their competitive advantage within an increasingly difficult economic environment (increased competition, globalization...). However, ICTs alone are not designed to create value. It is only when they are combined with other resources or implemented in a particular context that they actually create value. We will see how and under what conditions ICT and Internet in particular can play a role in marketing (1.1), but also a strategic role (1.2) in SMEs. We will also mention the managers of such businesses who, depending on their characteristics and involvement, can have a "facilitating" impact on the creation of value, thus representing a condition for the development of the SME (1.3).

\subsection{Internet as a lever for marketing and sales in SMEs ...}

In general, research shows that the use of ICT in SMEs is mainly focused on operational aspects with very little strategic orientation (Dyerson et al., 2009). According to Lee and Morrison (2010), a web presence offers several major advantages: cost reduction, revenue growth, targeted marketing, improved customer satisfaction, quality improvement, and response to customer needs. For many it is difficult to assess the precise results of Internet use for business. The approach for research therefore often focuses on perceived benefits, including sales and marketing dimensions, which remain a prime motivation among managers of SMEs (Mehrtens et al, 2001; Dyerson et al., 2009; Galloway et al., 2011; Sanders et al., 2014). 
One of the most important aspects concerns the development of e-commerce for businesses (Raymond et al., 2005; Bellaaj, 2009; Dyerson et al., 2009), but with very few companies offering the possibility for online order and payment (Lucchetti and Sterlacchini, 2004). Although it remains a marginal channel, SMEs also use ICT to develop a sophisticated pricing in real time, thus making it possible to use yield management techniques and dynamic pricing (Aldebert and Loufrani-Fedida, 2010). However, often, only part of the sales process is dematerialized, in particular upstream of the order (communication, catalogues...). This is partly explained by the lack of financial and human resources. Investment in appropriate software solutions represents a non-negligible cost for a SME. To basic equipment, the cost of training and maintenance also come on top of this (McDonagh and Prothero, 2000; Montazemi, 2006, Matthews, 2007; Dyerson et al., 2009).

When considering the commercial dimension, ICT and the Internet in particular also offer a means to improve customer relations by maintaining more regular and interactive links with some consumer segments and providing targeted information (Levenburg, 2005; Qureshil and al., 2009; Mattson, 2010). The visibility of the company (to enhance its reputation) is also one of the aspects that has been highlighted in some works (Mehrtens et al, 2001; chettiLuc and Sterlacchini, 2004). The development of websites and the reduced costs associated with their implementation offers the opportunity to create a showcase for companies with otherwise limited geographic reach and resources. Finally, improvement of communication remains one of the main motivations (see Questions 1, 2, 3 in our framework Table 1). 
In SMEs, the concept of competitive advantage is often restricted to the commercial aspect with a more customer focused dimension (Amabille and Gadille, 2003; 2006). Some companies however do engage in a real strategic thinking through the implementation of their website, especially when they have reached a stage of maturity and mastery of functionalities and services (the conclusion of the transaction and online payment is one of the most advanced phases). Through the Internet SMEs seek to achieve market differentiation. This differentiation consists of focusing not on lower prices but on a differential value perceived by the customer (Aldebert, 2008; Saarijärvi, 2012).

\section{2 ... Internet can also be a strategic positioning tool for SMEs.}

We have seen that ICT, particularly Internet can allow small companies to expand their sales and marketing strategy (dynamic pricing, visibility with new clients, etc). However, the more the smaller businesses use the Internet as a channel of communication and relationship with their customers, the more the way they are perceived changes and improves compared to their direct competitors and larger competitors (Morrison et al. 1999). This is especially true for SMEs that are at an advanced stage of Internet use.

The Internet is thus no longer a marketing tool, but also a trigger that can initiate strategic thinking (Monnoyer and Madrid, 2007). These authors mention that websites represent carriers for organizational and strategic resources that are only revealed through the congruence between ICT management and strategic choices. This congruence occurs for businesses that have an "advanced use" of the Internet. Scaglione et al. (2009) also show that the income growth rate of hotels that have their own domain name is higher than for those that have an Internet presence via regional portals: Internet becomes a lever for strategic positioning for companies that are at an advanced stage in their use of ICT. In previous research the Internet 
has been found to play a pivotal role in the creation of relationships in firms and, in most cases, is a mechanism for the creation of international opportunities in SMEs (Glavas and Mathews, 2014). It is therefore necessary to identify these companies. To this effect, two typologies seem relevant and relatively convergent in their conclusions: the typology of Daniel et al. (2002) and that of Aldebert (2008) ${ }^{4}$.

In the typology of Daniel et al. (2002), the authors identify four groups corresponding to different stages in the use of ICT: companies developing their first e-commerce services (stage 1), and those that use email to communicate with customers, suppliers and employees (stage 2). Those that have created a website and developed means to order online (stage 3) and finally, the "earlier adopters" (stage 4) that have introduced online ordering and develop means for online payment (last column of the table in Annex 1). This stage 4 corresponds to the pioneers (typology of Aldebert, 2008), they feature specific aspects: firstly, they view sales efforts not merely as distribution activities, but as an opportunity to create value. Also, strategically, their managers seek to acquire market segments through differentiation or specialisation and they are engaged in innovation, both in products, services, processes, types of customers, and in the internal structure of the company. This enables companies not only to become better known but also to be recognized. Finally, these companies anticipate on the market and adopt a pro-active behavior.

\footnotetext{
${ }^{4}$ Even though the categories of Daniel et al (2002) are older than a decade, these categories are still relevant because recent literature confirms the four categories (Aldebert, 2008, Hamad, 2014). In fact, even if the pace of change in the ICT sector is important, there are still businesses that are ahead in the use of technology and some that are still followers. Of course the characteristics intra-categories have changed somewhat (for example, nowadays the companies the least developed in terms of IT master IT better than 10 years ago, but the differences between categories remain the same: there are still groups much more in advanced than others).
} 
SMEs are therefore able to compete with larger players thanks to a clear and differentiating positioning, although they have much more limited means. They are then in a position to change consumers' perception using their website which becomes a showcase for their business and is thereby an important component of positioning (even if a website can be expensive, its value can be very important) (Morrison et al. 1999). In general, ICT has no direct effect on the positioning companies within their market or on company performance. However, through organizational processes and facilitating conditions, ICT will have an impact (both strategic and financial). Moreover, it has also been suggested that the Internet has enhanced the firm's ability to interact with international customers, suppliers and business partners through multiple, inexpensive integrated Internet technologies (Glavas and Mathews, 2014). In general, regardless of the size of the company, ICT entails changes in terms of organization and strategic alignment of resources, technology and strategy (Henderson and Venkatraman, 1993). Thus, according to Bergeron et al. (2001), ICT investment strategies must be co-aligned with the strategic behavior of companies in order to have a positive effect on performance (see Questions 4, 5 in our framework Table 1). It is therefore important to take into consideration the managers as they play an important role in this strategic alignment via the diffusion of technology and Internet use, especially in small firms.

\subsection{The role of small firms managers in the use of ICT}

Different characteristics make up the organizational profile of SMEs (Marchesnay, 2003; Julien, 1998): a strong centralization of management and decision-making, an implicit shortterm strategy and low breakdown of tasks favouring versatility rather than specialization. These characteristics have been identified in research on small businesses as they highlight not only the importance of the owner-manager in decision-making, especially regarding the choice of information technologies (Bergeron et al., 2001; Cragg et al., 2002; Monnoyer- 
Bordered, 2003, Ghobakhloo, M. and Hong Tang, S., 2013), but also the importance of the managers' perception of the choices made (Bergeron et al., 2001) and their interest for technology (Aldebert and Guegen, 2009; Spencer et al., 2012). Their interest in ICT is driven by practical results on process improvement and performance (Uwizeyemungu and Raymond, 2011; Connolly, 2005).

According to the literature (Mehrtens et al, 2001; Beckinsale et al., 2006; Glavas and Mathews, 2014), the first element explaining the use of ICT concerns the characteristics of the managers and their profile. This is also in line with the decision makers' level of perceived benefits of ICT (Pollard and Hayne, 1998; McDonagh and Prothero, 2000), especially when the way of conducting business is considered satisfactory internally. Conversely, psychological barriers and fear of change can be explanatory factors for the low level of use of ICT in SMEs (Acar et al., 2005) and a fortiori in SMEs (see Question 6 in our framework Table 1). Finally, lack of skills and technical and managerial expertise (Caldeira and Ward, 2002; Matthews, 2007; Dyerson et al., 2009; Qureshil et al., 2009) may be accentuated by the risk of dependence on publishers of software solutions who are in a privileged position through their technical expertise.

It is noteworthy however that the skills required for implementing ICT may be held by a person other than the manager. In general, the presence of an "expert" user, whether executive or another member of the company is likely to reduce the technological expertise barrier and facilitate the adoption of ICT tools. The availability of staff with technology-oriented skills is often a condition for their adoption in SMEs. The role of stakeholders close to the company, namely the customers and suppliers, as well as other informal influencers (local authorities, 
professional associations ...) is also among the explanatory factors, (Burgess, 2002). Media and software solution providers may also encourage managers to equip themselves with ICT.

As a conclusion to this first part, it appears that Internet applications are customer-relationship-management oriented both upstream (search for new customers, offering discounts, etc.) but also downstream (exchange of information, relationship marketing...). It also appears that the Internet can be a tool for strategic positioning, especially when the managers are involved and integrate the tool into their vision. Even if they do not possess the technical and managerial skills specific to ICT, thanks to the perceived benefits and network features, they are in a position to develop a marketing strategy and commercial activities on the Internet (cf. Table 1).

\section{[Insert Table 1]}

\section{Empirical study of four SMEs in the field of hospitality}

In this second part, we start with a presentation of the methodology used and the characteristics of SMEs studied (2.1). We then discuss the role of the Internet in a logical servuction ${ }^{5}$ showing that the SMEs studied use their website not only in a commercial and marketing perspective (2.2) but also to strengthen and develop their competitive positioning, particularly when the manager displays specific characteristics (2.3).

\subsection{Choice of qualitative methodology and description of the cases studied}

We deliberately focused our attention on SMEs that had a website so as to ensure there would be significant use of ICT. In France, although 50\% of small businesses have a website, only $12 \%$ use it to manage their reservations ("most advanced types” category mentioned in Part

\footnotetext{
${ }^{5}$ Neologism used by Eiglier and Langeard (1987) to describe the production of a service.
} 
1). To choose the relevant methodology we follow recommendations of Aldebert and Gueguen (2013) who argued that as hospitality is an emerging field, it is more useful to use case studies as a qualitative research method to understand complex ICT phenomena.

Multiple case studies, using non-probability purposive selection criteria was deemed to be appropriate for this research methodology. The use of multiple case studies gives a holistic perspective of a complex phenomenon. In-depth $2 \frac{1}{2} 2-3$ hour case interviews were conducted with owner/founders from four French tourism SMEs (fewer than 50 employees) in the Poitou-Charentes and Haute-Savoie regions, two famous tourism areas in France ${ }^{6}$. An interview protocol was developed to guide the interviews (see Frame 1).

\section{FRAME 1: CONTENT OF INTERVIEWS}

The semi-structured interviews with the managers were designed to understand the main uses, barriers and impacts of ICT in general and the Internet in particular in these SMEs. Thus, the interviews started by identifying their background (training, experience...) and that of his company (size, creation date, job ...). Then, we addressed the use of the Internet and the incentives that have driven the company to invest in equipment (type of ICT use, implementation strategy, means implemented ...). Finally, we concluded the interviews by seeking to identify the impact that introducing a website had on the activities of the company and the perceived benefits. We sought to fully understand the managers' motivations in relation to the specificities of the tourism sector, in which activity is cyclical and subject to strong competition, and occasionally involves much larger players.

\footnotetext{
${ }^{6}$ The concept of replication logic is used to select cases. Both literal replication and theoretical replication provides a foundation for outcomes through confirmation and analytical generalisability to the research (Yin, 2009), through a theory building process (Eisenhardt, 1989). That is, cases were chosen to give literal replication (predicted similarities in the results) and theoretical replication (contrasting results but for predicted reasons) so as to generate similarities and differences in the results from cases. For example, within the selection criteria all four firms are French SMEs. Similarities in the predicted responses (literal replication) were expected as these cases are all SMEs, at an advanced stage in their use of Internet and from the same tourism industry, while diversity in responses (theoretical replication) was also expected across small firms in comparison with medium firms. Theoretical replication was also expected across each case due to differences in geographical location (sea versus mountain).
} 
Our research question: "Under what conditions may the implementation of a website change the strategic positioning of small accommodation businesses in the tourism sector?" is characterized by both description and interpretation. We opted for a qualitative methodology, which is particularly relevant when the research goal is to explore, understand or generate ideas on why and how. Based on the literature reviewed in the first part of the article we defined an analytical framework that addressed several key issues (marketing dimension on one hand and on the other hand strategic dimensions).

We used this framework to conduct semi-structured interviews with the managers of the SMEs. We reformulated some of the questions several times during the interviews in order to check the consistency of answers. We systematically crossed the interview data in order to identify inferences with our questions and when there was any doubt, we contacted the managers concerned to deepen certain points. We went back to see them at least once after the first interview. Then, requests for clarification were made via email or by phone. Finally, case study methodology has a unique strength in its ability to deal with a full variety of evidence, such as documents, artefacts, observations and interviews (Eisenhardt, 1989; Yin, 2009). In this research marketing material, company documents, company website content and interviews with informal influencers (see Frame 2) were utilised to triangulate the results. The use of various sources of evidence in case studies allows the investigator to address a broader range of behavioural issues and aims at corroborating the same fact or phenomenon (Patton, 1990).

\section{FRAME 2: COMPLEMENTARY INFORMATION \& SECONDARY DATA}

The interviews were complemented by inner (internal memos, website, etc.) and external secondary data (press clippings). We crossed the managers' statements with the websites functionalities to avoid too much subjectivity, as well as with sales brochures and contributions by informal influencers. We 
also conducted six interviews with informal influencers and public and private organizations: Tourism advisor for the Chamber of Commerce of La Rochelle, sales manager of the group Hotels \& Chalets de Tradition, Commercial Director of RESO7 France and three members of RESO 7374. These players enabled us to have a broader and better understanding of the importance of the environment for SMEs, thus complementing the managers' statements. We were able to better understand the characteristics and peculiarities of activities in the tourism industry. The informal influencers and various organizations we encountered also made it easier for us to contact managers of SMEs and generated trust during the interviews.

Each of the SMEs had a website as well as other applications (software, CRM, etc.), constituting the businesses' information system, even if it was not necessarily very sophisticated. The website was the most important tool for all the managers interviewed. Therefore, we focused our attention on the website of small businesses with their features.

FRAME 3: LES 3 ÎLES (Island of Ré, Thalassotherapy) www.thalasso-larochellesud.fr/ Business: 50 employees; created in 1990; autonomy since 2008.

Activity: Health care + accommodation + catering. European customers.

Respondent: Director \& sales manager (46 years old); Technical Bachelor “mechanical engineering” and Business School.

ICT used: Practical information (promotional flyers), $360^{\circ}$ virtual tours, live webcam, local weather widget, online gift vouchers... management software thalassotherapy; Blog (in progress).

FRAME 4: LES CORMORANS (La Rochelle, Camping) www.cormoran.com/

Business: 3 to 10 employees, according to season; created in 2002; family run

Activity: Lodging. European customers

Respondent: Director (41 years old); Technical Bachelor / experience related to management of campsite

ICT used: Website translated into 6 languages, photos, videos, various information, possibility to book directly online, guestbook ... Management Software camping; GED (in progress).

FRAME 5: HÔTEL **** LE DAHU (Morzine, Lodging /Catering) www.dahu.com/

${ }^{7}$ RESO: Group of employers (in the tourism sector) who share employees according to the needs of their establishments. 
Business: 8 to 36 employees depending on the season; created in 1955; family-owned business taken over in 1986.

Activity: Lodging + catering + leisure activities (bike, ski ...), 50\% international clientele.

Respondent: Director (49 years old); Hospitality training / cook.

ICT used: Website translated into English, online bookings, newsletter, webcam, various news from the hotel, Intranet with password for regular customers, booking via ReservIT; package WinHôtel (CEGID).

FRAME 6: HÔTEL **** LE MACCHI (Châtel, Lodging /Catering) www.hotelmacchi.com/

Business: 6 to 36 employees according to seasons; creation in 1970; family-owned business, taken over in 1985.

Activity: Lodging + catering + leisure activities (hiking, gymnastics, ski...); $40 \%$ international clientele.

Respondent: Director \& chef (48 years old); Hospitality training / cook.

ICT used: Website in 5 languages, possibility to book online, webcam, special offers packages, gift vouchers. CRM to send targeted newsletters; Packages Reservations: PMS winHôtel and WinRestau (by CEGID).

To make the analysis of the use of websites by SMEs more concise, we present our results in the form of tables featuring the items of our analytical framework. We then comment on these tables showing each of the dimensions (Table 2: Marketing and sales dimensions; Table 3: Strategic dimension).

\subsection{Use of the Internet in a servuction approach}

The first observation is that the cases studied, which are businesses that are at an advanced stage in their use of Internet, use significant features of their website to develop sales and marketing dimensions. This is in accordance with the literature. The first three items of our interview grid confirmed this, even though there was some disparity between the SMEs.

\section{[Insert Table 2]}


The increase in notoriety and customer base acquired via the website (Q1) is cited by all managers. Thus, the main motivation for implementing a website was the possibility for businesses to expand their customer base in France and abroad. Very quickly, beyond the notoriety that their well-controlled interactive presence on Internet can provide, the managers realized the possibilities that a software solution and a dynamic website could offer, especially when translated into several languages. For example, the manager of the hotel The Macchi recently had their website translated into Russian in order to address this customer segment (who started coming to the hotel) and strengthen the establishment's reputation in Russia: "the website was first perceived as a need to attract customers but soon we perceived a potential for development and an axis of improvement". The manager of the campsite The Cormorants on the Ré Island explained that their website was translated into six languages and generates $30 \%$ of direct sales and over $50 \%$ of customer contacts (some customers finalize the transaction other than via the website). He also considers that the ratio of foreign customers has increased. Finally, the thalassotherapy The “3 Iles” generates $25 \%$ of its sales through its website (purchase of services, products and gift vouchers). These observations show that internationalization is becoming increasingly facilitated through the use of the internet (what Etemad et al. (2010) called “internatization”")

However, although the use of websites in SMEs makes it possible to implement new business techniques (Q2), these are not aggressive. The websites do not really serve to smooth out business activity because, even though the establishments have two seasonal peaks in winter

\footnotetext{
8 "Internetization" refers to the process of increasing adoption, diffusion, and deployment of internet-based technologies and processes that increasingly serve as the back bone of internationalization.
} 
and summer, the managers do not want to use marketing techniques that "devaluate" the services they offer. We can cite the example of The Cormorans campsite that has a website proposing promotions via banners for last minute offers that can adjust to the competition and booking capabilities. This strategy is not a pricing strategy and, although occupancy statistics provided by the tool could make it possible to propose discounts for the low season, SMEs do not wish to implement this. Yield management is thus used with caution because the keywords are "quality, service, satisfaction" and the managers focus on their image first: "tools should be in the service of our values (friendliness, etc.)" Hotel The Macchi. This result differs in part from the results of Dyerson et al. (2009) which suggested that the main motivation lay more in cost reduction than in value creation.

Our case study also confirms the impact of certain website features on customer loyalty (Q3). Our SMEs took a step further than those studied by Lucchetti and Sterlacchini (2004). For example, in order to personalize the relationship with customers, Le Dahu created a private club where customers can exchange photos, ideas, etc. with other customers after their stay. This club tells the life of the hotel throughout the year and maintains a link. The manager of this hotel also created a customer database (one sheet per customer with a hundred features): “I think continuously at improving services via technology” Hotel Le Dahu. This database, regularly updated and coupled to a CRM, enables them to send personalized offers and therefore strengthen customer loyalty (50\% of clients return regularly to Le Dahu). The manager of the Cormorants campsite on the Ré Island also reported that regular customers visit their website to keep in touch with new developments (a newsletter is also being developed). These different features proposed via the websites are designed to consolidate customer loyalty and increase sales for SMEs as these are very sensitive to small variations in their economic activity and cash flow. It also helps to maintain a personalized link that is important given the 
close relationship established between the managers and their clients. Some customers of both hotels were even considered as family.

However, the SMEs of our case studies faced difficulties that have already been identified in the literature (Montazemi, 2006): firstly, they must absorb the cost of software or building a dynamic and interactive website, including for example Content Management System... Especially regarding the website, the cost of referencing on search engines is very important (3 $\mathrm{K} €$ per year for operating the website for The Cormorants campsite, $18 \mathrm{~K} €$ per year for referencing on Google for the Thalassotherapy establishment). However, this cost is fully integrated into the budget and is regarded as a necessary expense to develop business.

\subsection{Internet used to strengthen the competitive position of small businesses, in particular through the role of the managers}

The work of Morrison and Taylor (1999) has shown that the advantages of ICT and Internet can be beneficial from a strategic point of view: cost reduction, strategy of differentiation, diversification, search for new income sources, or improving the performance of the organization. In the SMEs studied here, from a certain level of expertise, on the sales and marketing dimensions, the websites can lead to improved competitive positioning. The website helps to enhance differentiation but also the differential value perceived by the customer (Aldebert, 2008). This evolution in strategic positioning is not necessarily originally intended by the management, but if the perceived benefits are significant, they will gradually integrate the website as a component of the strategy. Thus, the Macchi Hotel gradually added services to anticipate requests from foreign customers who were acquired via the Internet: "if you stop 
providing new things, different experiences, you're dead !” Through a ripple effect, the website pushed the strategic positioning towards the upscale. Managers therefore have a role in the decision of aligning their organization to adopt a more qualitative competitive positioning. Another example is the case of Les Cormorants campsite. The creation of a website accompanied the upscale move of the campsite, which improved by proposing more qualitative services (Internet connection for customers, booking facilities, new mobile homes, etc). The manager told us during the interview: "my firm is one of the first movers in the ICT use regarding competitors and we have to keep this position”. For the thalassotherapy resort, the website helped strengthen the establishment thanks to a better visibility compared to its local competitors. The manager reported that the website and its functionalities allowed the implementation of a differentiation strategy especially "for offers considered as static."

\section{[Insert Table 3]}

Our observations show that the use of ICT in general improves the management of SMEs and requires changes in their organization, which starts with the back office using data from customers and prospects. For example, thanks to the synchronization of their various internal databases and access to data in real time, all of the businesses studied observed an improvement in their management. The data flowing through the website can be used for back office management, leading to an alignment of the IS components and optimised management (Q4). This fact is obvious for the two hotels: "I [the manager] do not regret the time when, every night I had to "synchronize" the data manually for each computer"(Hotel Le Dahu). They also reported time-saving and increased reliability thanks to the online booking feature. However, connecting different systems together requires a more significant investment and can 
entail a certain level of complexity, involving higher risks for managers. Implementing electronic solutions for the back and front office processes is often a gradual undertaking. Some establishments such as Les Cormorans campsite have taken a step further and have started to interconnect their systems in order to introduce remote management. The alignment between IS and the organization is based on a very pragmatic approach and a financial dimension as regarding the firm's size, as confirmed by the manager of Les Cormorans campsite ("We have a real payback with Internet website”).

Consequently, the competitive advantage gained by using websites enables small businesses to strengthen their differentiation (offering new services, targeting their sales offerings) and create close or even privileged relationships with their client (Bellaaj, 2009). This is a commercial and marketing approach that is favoured by managers and which often contributes to a quality-oriented and more upscale positioning (Q5). This result is also in line with Qureshil et al. (2009) and confirms the idea that a website is a showcase for companies but also a strategic positioning element in its own right. Our research shows that small businesses can use their website as a tool for differentiation with respect to their competitors, including, but not limited to, dimensions related to relationships with their customers.

Success in the use of a website also depends on a carefully thought out choice of technology with respect to the positioning of the company and the nature of its activities. The features proposed on the website must also stem from careful consideration as to the core business (and/or mission) because this will determine the services that should be offered and will influence consumers and prospects' perception. Thus, hotel managers must determine whether they offer accommodation, create emotions, etc. Various interviews with managers and informal influencers also mentioned the importance of monitoring the features and services in 
order to adapt them where necessary, taking into account not only changes in consumer behaviour but also the progressive establishment of competitors. For example, the two SMEs in the Charente-Maritime region planned to develop geolocation applications for mobile phones connected with their websites. This will enable them to offer services that are typically proposed by larger or more upscale establishments. The manager of Les Cormorants campsite even considers a complementarity approach with local shops in order to influence the prospects' choices.

The managers are not necessarily technophiles in that they do not necessarily buy the latest technology, etc. In our cases, they are in their forties or older and have not received any IT training. Rather, it is their ability to perceive the potential offered by technology as well as their innovative and risk-taking profile that seems to emerge (Q6). The managers we interviewed monitor the websites of their direct competitors (design, services, and occupancy); one of them, the manager of the thalassotherapy resort, used Netvibes ${ }^{9}$ as a web monitoring tool and told us: "If I could, I would bet everything on the internet to disseminate as much information as possible”. This finding is in line with Mehrtens et al. (2001) and Spencer et al. (2012): despite a lack of knowledge to pilot the implementation of software or run a website, managers will endeavour to master the tools by spending time to understand how these work (eg. Hotel Le Dahu) or in a first step will hire personnel with the necessary technical skills (eg. Hotel Le Macchi). The manager of the thalassotherapy resort confirms that "Recruiting a yield manager is a priority to develop real pricing strategy with the website”. This corresponds to an alignment of the establishment and resources on ICT.

\footnotetext{
${ }^{9}$ Netvibes may be defined as a free web portal customizable by each user based on their choice of RSS, API, etc.
} 
As for external stakeholders (suppliers, customers, etc.), these cannot be considered as indirect instigators: it seems as if, taken separately, these actors had no actual weight, however their aggregation is a motivator for ICT use. Informal influencers (Chambers of Commerce, clubs, etc.) are viewed as actors on which the manager can rely for guidance or rather to confirm choices. Thus, the sales manager at HCT can don many hats: "I am at the same time the initiator, a provider of technological solutions, an advisor. My role is to act as a "contact person" that enables hotel managers to rely on someone if needed. My presence reassures them and gives them confidence when it comes to taking new technology on board". His awareness-enhancing and monitoring role with respect to ICT is very important for managers of small businesses that have limited time and resources. In addition, informal influencers play an important liaising role between the businesses and the technical service providers that propose solutions. However, this proactive role refers back to the question of differentiation and one can ask whether in the long term, informal influencers might not cancel the differentiation asset of the "early adopters" and thus their competitive advantage by trying to disseminate ICT to all companies in the sector. However, triggers (strongly driven by informal influencers) are intimately interrelated and converge on the manager who seems to play a central role in the end.

\section{Conclusion}

Our research confirms that tourism and hospitality industries have adopted ICT to enhance operational efficiency, and most importantly to improve service quality and customer experience (Law et al., 2009). For small businesses in the tourist accommodation sector, implementing and using ICT in general and the Internet in particular makes it possible to achieve better visibility with their customers. It also encourages them to better structure their offering 
(improved readability) and better meet their clients’ expectations: a virtuous circle is established. Gradually, the optimization of the sales and marketing dimensions encourages them to adopt a more global strategic thinking and eventually enables them to clarify their competitive positioning. This represents an asset in terms of competition but also with respect to potential partners, making it easier for example to obtain funding and/or support. The performance of tourism firms can be improved by introducing new ICT, but positive impacts are especially obtained where ICT is combined with other strategic and managerial measures such as competence building and HRM (Blake et al., 2006). Managers have to deal with future ICT-related issues by integrating them into the company’s strategic management and business mission. A way to achieve this goal is to constantly upgrade the ICT knowledge and skills of staff, as in this way overall technical proficiency can be assured. (Law et al., 2009).

In terms of managerial implications, our research showed that:

- The Internet can be used as a means to innovate in the delivery of services thanks to upscale differentiation or niche targeting (personalization of offering, strengthening customer relationship, improving visibility versus larger competitors...);

- The website is the first representation of the positioning of the SME, allowing it to compete with larger companies, provided they offer the most advanced features;

- It is not necessary for the managers to be "early adopters," what matters is their awareness with respect to ICT and the importance of implementing such technology. Stakeholders, partners and personal/professional network can play an instigator or "support" for the managers: this environment helps them overcome the costs (human, financial, etc.) related to the installation and maintenance of a website in particular and ICT in general; 
- Finally, technology must serve a strategy, especially for small companies that have limited resources and cannot afford to go wrong. ICT alone do not create a competitive advantage but when combined with other resources they serve to support strategy and create value.

Our research naturally has limitations inherent to the qualitative approach, including the small number of respondents, which do not allow drawing general conclusions for small businesses in. However, in the Charente Maritime and Haute-Savoie regions of France, small businesses in the tourism industry that are advanced in terms of ICT use are few, which made it somewhat difficult to identifying and obtaining their agreement for an interview. Finally, the choice of the tourism sector can be considered a limitation because it is a sector that is ahead of others in terms of ICT adoption as mentioned in our introduction.

This exploratory study opens several perspectives. For instance, a quantitative study could be undertaken on a larger sample of small businesses, extending the scope to include three other types defined by Daniel et al (2002) in order to empirically test our results. The contribution of quantitative data would allow us to measure the contribution of ICT to the development of companies based on standard indicators (turnover, size ...). Finally, it could prove interesting to rethink existing typologies and to test whether it is necessary to define additional categories in connection with innovation linked to ICT and the Internet (LBS ${ }^{10}$ applications, non-contact payment, social networks, etc.) in order to better identify the businesses strategic choices, including small enterprises.

${ }^{10}$ LBS : Location Based Services 


\section{References}

Acar, E., Kacak, I., Sey, Y and Arditi D. (2005) 'Use of information and communication technologies by small and medium-sized enterprises (SMEs) in building construction', Construction Management and Economics, 23, pp.713-722.

Aldebert, B. (2008) ‘Technologies de l'information et de la communication : un outil stratégique pour les petites et moyennes entreprises touristiques', Management et Sciences Sociales, 5, pp.11-30.

Aldebert, B. and Gueguen G. (2009) 'Intérêt du dirigeant de PME touristiques pour les TIC: quels effets sur l'utilisation de la performance ?'. $14^{\text {ème }}$ colloque de l'AIM.

Aldebert, B and Loufrani-Fedida, S. (2010) 'Repérer les compétences pour mieux comprendre le processus d'innovation. Le cas d'une TPE touristique', Revue Internationale P.M.E, 23(1), pp.33-61.

Aldebert, B. and Gueguen G. (2013) 'TIC et performance : rôle du dirigeant de PME touristiques’, Revue internationale P.M.E, vol 25, n³-4, p. 213-233.

Amabille, S and Gadille S. (2006) 'Les usages d’Internet, facteurs de compétitivité de la «PME réseau » ?’, Finance Contrôle Stratégie, 9(1), pp. 35-57.

Amabile, S and Gadille M. (2003) 'Les NTIC dans les PME : Stratégies, capacités organisationnelles et avantages concurrentiels’, Revue Française de Gestion, (29) 144, pp.43-63.

Beckinsale, M., Levy M and Powell P. (2006) 'Exploring Internet Adoption Drivers in SMEs’, Electronic Markets, 16(4), pp.361-370.

Bellaaj, M. (2009) 'Effets modérateurs des capacités complémentaires dans le e-commerce. Application au contexte des PME', Revue Internationale P.M.E, 22(2), pp.9-35.

Bergeron, F., Raymond, L. and Croteau A.M. (2001) 'Comportements stratégiques, choix et gestion des systèmes d'information : contribution à la performance', SIM, 4(6), pp.5-26. 
Blake, A., Gillham, J. and Sinclair, M.T. (2006), 'CGE Tourism Analysis and Policy Modelling', In: Dwyer L, Forsyth P (eds) International Handbook on the Economics of Tourism, Edward Elgar ,Cheltenham, pp.301-315.

Bonn, M.A., Furr, H.L and Susskind, A.M. (1998) 'Using the Internet as a Pleasure Travel Planning Tool: an Examination of the Sociodemographic and Behavioral Characteristics Among Internet Users and Nonusers', Journal of Hospitality \& Tourism Research, 22, pp.303-317.

Burgess, S. (2002) Managing Information Technology in small business: Challenges and solutions, Idea Group Publishing.

Caldeira, M.M and Ward, J.M. (2002) 'Understanding the successful adoption and use of IS/IT in SMEs: an explanation from Portuguese manufacturing industries', Information Systems Journal, 12(2), pp.121-152.

Cragg, P., King, M and Hussinc, H. (2002) 'IT alignment and firm performance in small manufacturing firms', The Journal of Strategic Information Systems, 11(2), pp.109-132.

Connolly, D. J. (2005) 'Research methods: A guide to using the case study method to explore hospitality information technology phenomena', Information Technology in Hospitality, 4(1), pp.23-46.

Daniel, E., Wilson, H and Myers, A. (2002) 'Adoption of e-commerce by SMEs in the UK, towards a stage model’, International Small Business Journal, 20(3), pp.253-270.

Dyerson, R., Harindranath, G and Barnes, D. (2009) 'National Survey of SMEs' Use of IT in Four Sectors', The Electronic Journal Information Systems Evaluation, 12(1), pp.39-50

Eiglier, P. and Langeard, E. (1987) Servuction, le marketing des services, Collection Stratégie et management, Paris : McGraw-Hill.

Eisenhardt, K.M. (1989), 'Building theories from case study research’, Academy of Management Review, 14(4), pp.532-550. 
Etemad, H., Wilkinson, I. and Dana, L.P. (2010) 'Internetization as the necessary condition for internationalization in the newly emerging economy', Journal of International Entrepreneurship, 8(4), pp.319-342.

Galloway, L., Sanders, J. and Deakins, D. (2011) 'Rural small firms' use of the internet: From global to local', Journal of Rural Studies, 27(3), pp.254-262.

Ghobakhloo, M and Hong Tang, S. (2013) 'The role of owner/manager in adoption of electronic commerce in small businesses: The case of developing countries', Journal of Small Business and Enterprise Development, 20(4), pp.754 - 787.

Glavas, C. and Mathews, S. (2014) 'How international entrepreneurship characteristics influence Internet capabilities for the international business processes of the firm', International Business Review, 23(1), pp.228-245.

Hamad, H. (2014) Antecedents of business-to-business e-commerce adoption and its effect on competitive advantage in manufacturing small and medium-sized enterprises: A comparative study of United States of America and Egypt, Thesis, University of Plymouth.

Harindranath, G., Dyerson, R. and Barnes, D. (2008) 'ICT Adoption and Use in UK SMEs: A Failure of Initiatives?', The Electronic Journal Information Systems Evaluation, 11(2), pp.91-96.

Heijden, van H. (2003) 'Factors influencing the usage of Websites: The case of a generic portal in the Nether- lands', Information \& Management, 40, pp.541-549.

Cass, A. and Fenech, T. (2003) 'Web retailing adoption: Exploring the nature of internet users Web retailing behaviour', Journal of Retailing and Consumer Services, 10, pp.81-94. Henderson, J.C and Venkatraman, N. (1993) 'Strategic Alignment: leveraging Information Technology for Transforming Organizations’, IBM Systems Journal, 32(1), pp.4-16. Julien, P.A. (1998) ‘Les PME, bilan et perspectives’, Edition Economica Paris, 2eme édition, $351 \mathrm{p}$. 
Law, R., Leug, R. and Buhalis, D. (2009) 'Information technology applications in hospitality and tourism: A review of publications from 2005 to 2007', Journal of Travel \& Tourism Marketing, 26, pp.599-623.

Lee, J and Morrison, A.M. (2010) 'A comparative study of web site performance’, Journal of Hospitality and Tourism Technology, 1(1), pp.50-67.

Levenburg, N.M. (2005) “Does Size Matter? Small Firms’ Use of E-Business Tools in the Supply Chain’’, Electronic Markets, 15(2), pp.94-105.

Lucchetti, R and Sterlacchini A. (2004) 'The Adoption of ICT among SMEs: Evidence from an Italian Survey’, Small Business Economics, 23, pp.151-168.

Marchesnay, M. (2003) 'La petite entreprise : sortir de l'ignorance', Revue Française de Gestion, 144, pp.107-118.

Matthews, P. (2007) 'ICT Assimitation and SME Expansion', Journal of international Development, 19, pp.817-827.

Mattson, J. (2010) 'Developing a strategic abstraction tool for service innovation', Journal of Strategic Marketing, 18, pp.133-144.

Mcdonagh, P and Prothero, A. (2000) 'Euroclicking and the Irish SME: Prepared for ecommerce and the single currency’, Irish Marketing Review, 13(1), pp.21-33.

Mehrtens, J., Cragg, P.B and Mills, A.M. (2001) 'A model of Internet adoption by SMEs', Information and Management, 39(3), pp.165-176.

Miles, M.B. and Huberman, A.M. (1994) Qualitative Data Analysis: An expanded sourcebook, $2^{\text {nd }}$ ed., Sage: London \& Thousand Oaks, California.

Monnoyer Longé, M.C. (2003) ‘ PME et technologies de l’information. De la prise de décision à la mise en œuvre’ Revue Internationale P.M.E, 15(3-4), pp. 11-36.

Monnoyer Longé M.C. and Madrid, C. (2007) 'Intégrer les sites web dans les stratégies’, Revue Française de Gestion, 4(173), pp.145-155. 
Montazemi, A.R. (2006) 'How They Manage IT: SMES in Canada and the U.S.', Communication of the ACM, 49(12), pp.109-112.

Morrison, A.M., Taylor, S., Morrison, A.J and Morrison, A.D. (1999) 'Marketing small hotels on the World Wide Web', Journal of Information Technology \& Tourism, 2, pp.97-113. Patton, M.Q. (1990), 'Qualitative evaluation and research methods', Newbury Park: California Sage.

Pollard, C.E and Hayne, S.C. (1998) 'The changing faces of information systems issues in small firms’, International Small Business Journal, April-June, 16(3), pp.70-87.

Qian, C.Z., Clarke, G.R. and Halewood, N. (2006) The Role of ICT, Doing Business Information and Communications for Development - Global Trends and Policies, World Bank ed., Washington DC.

Qureshil, S., Kamal, M and Wolcott, P. (2009) 'Information Technology Interventions for Growth and Competitiveness in Micro-Enterprise', International Journal of E-Business Research, 5(1), pp.117-140.

Raymond, L. Bergeron, F and Blili, S. (2005) 'The assimilation of E-business in manufacturing SMEs: determinants and effects on growth and internationalization', Electronic Markets, 15(2), pp.106-118.

Reix, R. (2002), Systèmes d'Information et management des organisations, ed., Gestion, Paris.

Saarijärvi, H. (2012) ‘The mechanisms of value co-creation’, Journal of Strategic Marketing, 20(5), pp.381-391.

Sanders, J., Galloway, L. and Bensemann, J. (2014) 'Investigating the Relationship Between Scottish Rural Small Firms’ Social Networks, Extra-local Market Diversification and Internet 
Usage’, Exploring Rural Enterprise: New Perspectives on Research, Policy \& Practice (Contemporary Issues in Entrepreneurship Research, Volume 4) Emerald Group Publishing Limited, pp.9-33.

Scaglione, M., Schegg, R and Murphy, J. (2009) 'Website adoption and sales performance in Valais’ hospitality industry’, Technovation, 29, 625-631.

Sigala, M. (2004) 'Reviewing the profile and behaviour of Internet users: Research directions and opportunities in tourism and hospitality', Journal of Travel \& Tourism Marketing, vol $17, n^{\circ} 2 / 3$, pp.93-102.

Spencer, A. J., Buhalis, D. and Moital, M. (2012) 'A hierarchical model of technology adoption for small owner-managed travel firms: An organizational decision-making and leadership perspective’, Tourism Management, 33(5), pp.1195-1208.

Sullivan, B.C. (1985) ‘Economics of Information Technology’ International Journal of Social Economics, Bradford, 12(1), pp.37-53.

Rogers, E. M. (1962) Diffusion of innovations, New York: The Free Press.

Uwizeyemungu, S. and Raymond, L. (2011) 'Information technology adoption and assimilation: towards an adapted framework for service sector SMEs', Journal of Service Science and Management, 4, 2, pp.141-157.

Yin, R. (2009) Case study research: Design and methods, 4th ed., Newbury Park, CA: Sage Publishing. 
Table 1: Analytical framework used for our case studies

\begin{tabular}{|l|l|}
\hline 1 & $\begin{array}{l}\text { Does the website allow increasing the visibility of SMEs and the cus- } \\
\text { tomer base? }\end{array}$ \\
\hline 2 & Does the website allow implementing new marketing techniques? \\
\hline 3 & Does the website allow retaining and maintaining the customer base? \\
\hline 4 & Does the website require alignment / modification of the organization? \\
\hline 5 & $\begin{array}{l}\text { Does the website allow to initiate a reflection on the creation of value } \\
\text { and improve competitive positioning? }\end{array}$ \\
\hline 6 & $\begin{array}{l}\text { Does the manager play a major role in the creation and use of the web- } \\
\text { site, particularly in terms of profile and network? }\end{array}$ \\
\hline
\end{tabular}

Table 2: Development of sales and marketing dimension via websites

\begin{tabular}{|l|l|c|c|c|c|}
\cline { 2 - 5 } \multicolumn{2}{l|}{} & Les 3 Iles & $\begin{array}{c}\text { Les Cor-mo- } \\
\text { rans }\end{array}$ & $\begin{array}{c}\text { Hôtel } \\
\text { Le Dahu }\end{array}$ & $\begin{array}{c}\text { Hôtel } \\
\text { Le Macchi }\end{array}$ \\
\hline 1 & $\begin{array}{l}\text { Does the website allow in- } \\
\text { creasing of the visibility of } \\
\text { SMEs and the customer } \\
\text { base? }\end{array}$ & ++ & +++ & +++ & +++ \\
\hline 2 & $\begin{array}{l}\text { Does the website allow the } \\
\text { implementation of new mar- } \\
\text { keting techniques? }\end{array}$ & ++ & + & ++ & + \\
\hline 3 & $\begin{array}{l}\text { Does the website allow to } \\
\text { retain and maintain the cus- } \\
\text { tomer base? }\end{array}$ & ++ & ++ & +++ & ++ \\
\hline
\end{tabular}

Scale from the interviews and verbatims (the number of + indicates the importance of the website in the marketing strategy and its place compared to others traditional marketing tools):

+ : website considered as a simple tool regarding tools and techniques used by SMEs

++ : website considered as a complementary tool regarding tools and techniques used by SMEs

+++ : website considered as a new and strategic tool to create added value for the SMEs

Table 3: Evolution of strategic positioning

\begin{tabular}{|l|c|c|c|c|c|}
\cline { 3 - 5 } \multicolumn{2}{l|}{} & Les 3 Iles & $\begin{array}{c}\text { Les } \\
\text { Cormorans }\end{array}$ & $\begin{array}{c}\text { Hôtel } \\
\text { Le Dahu }\end{array}$ & $\begin{array}{c}\text { Hôtel } \\
\text { Le Macchi }\end{array}$ \\
\hline 4 & $\begin{array}{l}\text { Does the website require } \\
\text { alignment / modification of } \\
\text { the organization? }\end{array}$ & + & ++ & +++ & ++ \\
\hline 5 & $\begin{array}{l}\text { Does the website allow a re- } \\
\text { flection on the creation of } \\
\text { value and improve competi- } \\
\text { tive positioning? }\end{array}$ & ++ & +++ & ++ & ++ \\
\hline 6 & $\begin{array}{l}\text { Does the manager play a } \\
\text { major role in the creation and }\end{array}$ & +++ & +++ & +++ & +++ \\
\hline
\end{tabular}




\begin{tabular}{|l|l|l|l|l|}
\hline $\begin{array}{l}\text { use of the website, particu- } \\
\text { larly via his/her profile and } \\
\text { network? }\end{array}$ & & & \\
\hline
\end{tabular}

Scale from the interviews and verbatims (the number of + indicates the impacts of the website) for Q4 and Q5: + : weak impact of the website on processes and organization (website as a tool among others)

++ : middle impact of the website on processes and organization (changes in tasks nature, adjustment of processes or tools, etc.)

+++ : high impact of the website on processes and organization (creation of new tools, elaboration of new marketing strategy, development or add new skills in the organization, etc.)

For the question 6, the scale is based on the traditional profile of innovation early adopter (technical skills, relationships in their networks, adoption of new technologies, etc). Early adopters (+++) appropriate innovations faster than other people and they are also more involve in product development as compared to the early majority (++). We precise that small firms are not innovators in the Rogers'classification (1962) but early adopters. Aldebert and Gueguen (2013) demonstrate in a recent study that small business manager's interest and perception promotes a great use of ICT in his firm. 